\title{
The Representation of Gays and Lesbians in South African Cinema 1985-2013
}

\author{
By Martin P. Botha
}

Fall 2013 Issue of KINEMA

\section{THE REPRESENTATION OF GAYS AND LESBIANS IN SOUTH AFRICAN CINEMA 1895-2013}

Despite South Africa's progressive constitution which prohibits discrimination against gays and lesbians, as well as a strong gay movement, South African cinematic images of gay men and women are limited and still at the margin of the South African film industry. One ends up with less than 20 short films, a few documentaries and less than 10 features with openly gay and lesbian characters in the past 114 years of South African cinema. Under apartheid, gay and lesbian voices in film and television were silenced. In a 20-year study of the representation of gays and lesbians in African, Asian and Latin American cinema (Botha 2003; 2012; Botha \& Swinnen 2010), the author has noted that homosexual experience is unique in South Africa, precisely because of South Africa's history of racial division and subsequent resistance. South African gay identities have been formed by a long history of racial struggle.

These gay identities were also deformed by an oppressive system, which classified homosexuals into those with freedom and those without. Apartheid legislated who South Africans were, where they could live, with whom they could associate and even what kind of sex they could have. Asserting a lesbian and gay identity in South Africa became a defiance of the fixed identities - of race, ethnicity, class, gender and sexuality that the apartheid system attempted to impose upon all of South African society (Gevisser \& Cameron 1994; Peach 2005; 2007).

Because their sexuality runs counter to that of the cultural mainstream or dominant culture of apartheid, lesbians and gay men have been, for the greater part of South Africa's film's history, made invisible. This was also particularly true in the United States from 1934 to 1961 when censorship prohibited any depiction of sexual "perversion" (Russo 1987). When gays and lesbians did appear on the screen, it was most often in stereotypical ways, namely the "sissy", effeminate male and the "butch" or manly woman. During the sixties, gays and lesbians were mostly portrayed as either victims of violence or ridicule, or as villains (Russo 1987). Out of 32 US films with major homosexual characters from 1961 through 1976, thirteen featured gays who committed suicide and 18 have the homosexual murdered by another character. The stereotypes of gays and lesbians, which were examined in Russo's landmark book The Celluloid Closet (1987) unfortunately prevailed in most South African features up to 2013.

\section{Afrikaans language cinema}

Homosexuality is almost non-existent in South African cinema up till 1985. The Afrikaans language cinema has few images of openly gay characters. One could attribute this to the conservative attitude of Afrikaners at that stage towards the films. Afrikaners wanted their ideals visualised in these films. This idealistic conservatism was characterised by an attachment to the past, to ideals of linguistic and racial purity and to religious and moral norms. Homosexuality had no place in this world view (Botha 2003). The films had to subscribe to these conservative and homophobic norms to do well at the box office. The films seldom attempted to explore a national cultural psyche. As such, they were a closed form, made by Afrikaners for Afrikaners, with little or no attention to their potential to say something important about their society to an international audience (Pretorius 1992).

The type of realism that could have analysed Afrikaner culture in a critical manner was avoided. Instead use was made of folk stereotypes that showed the Afrikaner as chatty, heart-warming and lovable in a comedy tradition or as beset by emotional problems that had little to do with society but much to do with the mainsprings of western melodrama about mismatched couples overcoming obstacles on the path to true love. Afrikaans characters were always heterosexual, and although a film like Forty Days (1979) hinted at the 'perverse' homosexual subculture of Hillbrow, this subculture is not really given any human face and remains something sinister. Another film, Seuns van die Wolke (1975), presented audiences with vague homoerotic 
images of half-naked men, but nothing daring was portrayed. The story is set against the Second World War and deals with two hostile pilots. When they are forced to rely on each other for survival a strong friendship develops between them. There is a hint of a possible homoerotic bond, but it is never really explored. Afrikaans-language films also ignored the socio-political turmoil as well as the realities experienced by black South Africans under apartheid.

Even in the 1990s and $21^{\text {st }}$ century Afrikaans-language cinema and television struggled to offer viewers any three-dimensional gay characters. In the comedy Lipstiek Dipstiek (1994) the two gay characters (in supporting roles) are a stereotyped, flamboyant sissy and a villainous yuppie, who end up with each other. In Kaalgat tussen die Daisies (1997) drag queens in an unrecognisable gay pub appear before old heterosexual men with no gay men in sight and the leading gay character turns out to be an undercover cop who is playing gay as a drag queen to finalise a case! Leon Schuster's slapstick comedies (There's a Zulu on My Stoep, 1993; Sweet 'n Short, 1991; Panic Mechanic, 1996) are full of homophobic and derogatory fag jokes and references. Only recently were gay characters introduced in popular daytime television soap operas such as Egoli.

\section{Attempts in the 1980s}

In many respects, the early 1980s signified an opening up for South Africa, socially as well as politically (Gevisser \& Cameron 1994). At the beginning of the decade, President P.W. Botha began instituting a 'reform' programme (which was balanced with heightened repression) and, in the aftermath of the Soweto upheavals in 1976, a massive upsurge of black liberationist activity swept through the townships. For the very first time since the Nationalist Party came to power in 1948, there was a tangible sense that the decades of white Afrikaner Calvinist rule were coming to an end and that the strict apartheid packaging off of people would give way to a more liberated and integrated society. Those years, despite two states of emergencies, saw the beginnings of deracialisation and the establishment of anti-apartheid counter-cultures, which vociferously questioned the religious and political restrictions of the previous 40 years. Within gay politics gay movements such as Lesbians and Gays against Oppression (LAGO), which became the Organisation of Lesbian and Gay Activists (OLGA) as well as black gay activist Simon Nkoli's Gay and Lesbian Organisation of the Witwatersrand (GLOW) became part of the broad democratic movement (Gevisser \& Cameron 1994).

In the 1980s two South African features were made with gay characters: Cedric Sundström's thriller The Shadowed Mind (1988) and Helena Nogueira's lesbian love story Quest for Love (1987), set against political turmoil in Southern Africa. The latter starred two popular Afrikaans language actresses, Jana Cilliers and Sandra Prinsloo. Prinsloo played Dorothy, a marine biologist, and Cilliers the political journalist Alexandra. The film used flashbacks to create a rhythm between Alexandra's memory and her current self-discovery, climaxing in her reunion with Dorothy. Voice over and letters are also used to suggest Alexandra's verbal control over experience and her analysis of the political and sexual worlds in which she finds herself. It is a complex structure, but Nogueira manages to create a film of emotional power, which also presents us with three-dimensional lesbian characters (Botha 2003).

The film starts with the arrest of Alexandra and her lover, Michael, for accusing South Africa of military intervention in Mozania (Mozambique). Alexandra emerges from prison a year later, goes to Mozambique to stay with Dorothy and finds she has to wait 2 weeks for her friend's return. This waiting period forces Alexandra to reflect on her relationships, her ideological position and her attempts to come to terms with Africa. Dorothy, however, has become an integral part of Africa through her deeds as a biologist. While one woman is experiencing conflicts regarding her role, the other is at ease with herself and her sexual orientation (Botha 2003).

The flashbacks mostly concern discussions and arguments between Alexandra and Dorothy regarding the values of political activism against those of political common sense and pragmatism. Alexandra favours intellectual engagement. Dorothy chooses community involvement. She returns to her home country to try and help the people with her scientific knowledge and ecological and humanitarian concerns. Nogueira's portrayal of a lesbian love affair against the background of South Africa's military destabilisation campaigns in neighbouring countries is one of the highlights of new South African gay cinema. More than 15 years after its first release in 1988 the film still comes across as a powerful and complex portrait of political and sexual themes within a contemporary South African setting.

Set in an extremely unlikely therapy centre for weird sexual malfunctions, The Shadowed Mind (1988) offers 
images of full-frontal male nudity and homosexual behaviour among inmates (Botha 2003). Shot in disused railway warehouses in Pretoria, director Cedric Sundström created a stylised horror movie. The script, however, was written in a space of 1 week, which unfortunately led to weak characters and a very loose narrative structure.

Dialogue was improvised but is never really convincing. The film tries to delineate the blurred lines between sanity and madness. Homosexuality, thus, is placed within that context. The asylum becomes a microcosmic battlefield in which a war of emotions is waged between the inmates. In that respect Sundström is successful: An atmosphere of menace is maintained throughout the film, and the style and photography is sometimes breath-taking. But the film cannot escape the old psychoanalytical notion that homosexuality is an illness, and finally, the bisexual male character, who engages in sex with another male, is brutally murdered, joining Vito Russo's list of murdered gay characters in film history.

\section{Post-apartheid attempts: Chronicles of gay and lesbian lives}

No other film in South African film history to date chronicled the lives of lesbian and gays in the way the full-length documentary The Man Who Drove with Mandela (1988) has done (Botha 2003). Winner of an award at the Berlin International Film Festival it was directed by Greta Schiller and researched by Mark Gevisser, co-writer of the outstanding compilation on South African lesbian and gay lives, Defiant Desire (1994). It is a semi-biographical portrait of Cecil Williams, who was being 'chauffeured' by Nelson Mandela on the day the future president was arrested. Williams was a communist and ANC activist. He was a dedicated campaigner and recruiter of ANC members, and he was also flamboyantly gay. Williams was well known in the Johannesburg of the fifties, as a socialite and a successful director of plays that belonged to the great liberal tradition of the earlier part of the century. He directed some of the country's top actors in their youth, staging contemporary classics in the city's lost and forgotten Library Theatre.One indigenous work remains notable. Called The Kimberly Train - directed in 1959 - it was about a love affair across the apartheid divide. In those days, because theatres were segregated, the white actress playing a "coloured" woman darkened her make-up by a couple of shades (Botha 2003).

The facts surrounding Williams's life during the apartheid era in the fifties and sixties are conveyed to the audience via excerpts from a biographical one-man play performed by Corin Redgrave. It is filmed on a set, with highly theatrical lighting, and Redgrave's sensitive performance as Cecil Williams gives one a keen sense of this openly gay man. These performed fragments are integrated within interviews with party activists, who worked closely with Williams, by his colleagues in the theatre, black and white, and by wonderful archive footage of South African history over the past 40 years, which contextualises Williams's life vividly. But it is not just the life story of Cecil Williams. It remains a fascinating, deeply moving chronicle of how political and intellectual dissenters of the 1950s and 1960s lived and operated in South Africa. The audience glimpses the way the shebeens in the townships and the nightclubs worked, and how theatre in its unique way became a voice for the marginalised (Botha 2003). The film becomes a wonderful kaleidoscope of stories fitted vividly together but hinged on the fact that on the day Mandela was captured, the comrade in the car with him was a white gay man, whose lifestyle was known to prominent leaders like Walter Sisulu and Mandela in the ANC and the South African Communist Party. Albie Sachs, an ANC activist, told Gevisser during his research phase that if one wants to understand why the older generation of ANC comrades is so receptive to the notion of gay equality in the constitutional debate one needs to go back and look at the role that Williams, a gay man and a communist, played within the liberation movement (Botha 2003).

Gevisser's ground-breaking research into South African gay and lesbian lives forms the foundation of The Man Who Drove with Mandela and his book Defiant Desire (Gevisser \& Cameron 1994). One overwhelming conclusion in his research points to the fact that there is no single, essential 'gay identity' in South African society. It also destroyed the claim that homosexuality is a bourgeois western phenomenon which contaminates the purity of African civilisation. Homosexuality exists and flourishes in so-called black communities and cultures of South Africa, despite oppression. By the mid-1950s, the times depicted by The Man Who Drove with Mandela, gay subcultures existed in major cities like Johannesburg, Cape Town and Durban. The rapid urbanisation, especially of whites, offered urban gays and lesbians, living apart from their families and predominantly conservative home communities, a way to 'come out' as part of a gay subculture. With the exception of Cape Town, where there had been a gay culture based in the Cape Malay communities, these subcultures were mostly white, male and middle class. 
In South Africa's apartheid history, however, the move of whites into cities was parallelled by a system of black migrant labour: single-sex compounds, where men were divorced from home communities, basically created opportunities for homosexual encounters. The end of the Second World War saw a larger percentage of single people living away from their families. Hillbrow, in Johannesburg, with its high-density accommodation, became an obvious neighbourhood for single people, and many gays moved there. Lesbians, despite being ignored by anti-gay legislation in South Africa, experienced far greater pressure to remain closeted and had far fewer public meeting places than men. While women's organisations focused on workplace rights and anti-apartheid struggle during the fifties and sixties, it did not address issues of sexuality or situate itself within feminist ideology.

Without a feminist movement and virtually no subculture to refer to, lesbians found it more difficult than gay men to find a space. On the whole, lesbian social life at the time revolved around private parties in private homes, while white gay men had the opportunity to interact in pubs and public places, such as parks or at the beachfront in Durban or Cape Town. 'Coloured' gay men became very much the texture of District Six, a racially mixed neighbourhood in Cape Town, which was finally demolished by apartheid (Gevisser \& Cameron 1994). A lot of activities were centred along Hanover Street, where many gay men rented rooms and socialised by going on 'salon crawls' - visiting the many gay hairdressing salons. Gay life thrived in District Six, Athlone, Woodstock and Salt River, and a drag culture evolved here. Within the 'coloured' communities of Cape Town there were all-gay drag sports clubs, such as the District Six Netball Team, which participated in the women's league. These netball teams, like the drag performers, have been a constant in the Western Cape 'coloured' culture and have their latest incarnation in the Lavender Hill Netball Team, which competed on the Cape Flats during the 1990s.

The history of gay life in Western Cape 'coloured' communities is beautifully captured by two documentaries of Jack Lewis, namely Sando to Samantha aka the art of dikvel (1998) and especially A Normal Daughter: The Life and Times of Kewpie of District Six (1997). Gay life has flourished over the years in these communities, probably since sexual dissidence is more tolerated in a hybrid, Creole society like that of South African 'coloureds' than in supposedly coherent societies with strong patriarchal mythologies and traditions, like those constructed by the African and white Afrikaner nationalist movements in South Africa (see Sonnekus 2013).

However, there was very little interaction between the 'coloured' and white gay communities in Cape Town. And only in the 1980s did black men and women begin to play an active role in gay politics (Botha 2003). There remains a long history that remains as yet unwritten of the repression and regulation of sexuality by the Apartheid State during its more than four-decade hold on power (Gevisser \& Cameron 1994; Peach 2007). Out of fragments, sensational press reports and oral histories a historical researcher will probably one day reconstruct a narrative which will deal with gay and lesbian oppression in South Africa as well. Racist legislation and iron-fisted rule have, since the earliest days of Nationalist Party rule, gone hand in hand with an obsessive interest in sexual policing. This policing was based on the values of Christian Nationalist apartheid ideology: the need to keep the white nation sexually and morally pure so that it had the strength to resist black communist onslaught. Sex laws drafted during the heyday of apartheid in the fifties and sixties prescribed tough penalties for a range of sexual offences.

Apart from notoriously criminalising interracial sex, the Immorality Act of 1957 also made everything from prostitution, to soliciting for immoral purposes, to sex with mentally retarded persons illegal and punishable by prison sentences of up to 6 years. In 1985, the racial provisions of the act were altered, but its other provisions were kept intact. Freedoms of sexual speech and association were virtually unheard of until the ANC-led government came into power in 1994. Before that historic event the South African Publications Board censored any representations of sex or any sexual views that strayed too far from what was defined as moral within a narrow, conservative world view. In practice this meant, among other things, that anything with the sole purpose of providing sexual stimulation - such as sexy pictures or writing - was undesirable and hence illegal.

Even educational videos on safe-sex practices for gay men experienced censor problems as late as the beginning of the 1990s. Concerted attacks on the gay community in South Africa from the mid-sixties consisted of occasional incidents of victimisation and the launching of a vigorous legislative campaign against it (Gevisser 
\& Cameron 1994). The trigger of the campaign was a police raid on a house in Forest Town in Johannesburg in January 1966, where 300 gay men were dancing and kissing. It was recommended to the Minister of Justice that laws should be tightened to combat homosexuality. The issue was taken to parliament. A select committee of parliamentarians was established, at the minister's request, to look into the matter more closely.

The report of this investigation, the only serious policy-making initiative to ever come from the Nationalist Party government on the issue of homosexuality, was published in 1968. It stated that homosexuality was spreading because older men and women were seducing teenagers. A gay action group, formed in the aftermath of the party raid, paid legal and expert witnesses to make representations. The anti-criminalisation lobbying was not wasted, since the committee was talked out of the idea of new laws aimed at gay sex in general. However, the committee did go ahead with reactionary recommendations regarding gay parties and sex with teenagers. Any sexual acts between men at a party were to be banned, including kissing; the age of consent for male homosexual acts was to be raised from 16 to 19 years, and the manufacture or distribution of any article intended to be used to perform an unnatural sexual act was to be prohibited. These recommended amendments to the Immorality Act were passed into law in 1969. Just after the legislation was passed a clampdown on outdoor meeting places for gay men as well as routine police surveillance of gay clubs, bars and parties occurred, deep into the seventies and eighties.

Despite initial hostility the authorities agreed in 1990 to allow a lesbian and gay pride march through the streets in the metropolitan centre of Johannesburg. Censorship, however, regulated writing and audio-visual expression regarding gay lives until the first democratic government came into power in 1994. Before 1994 the censorship of gay material was severe. Magazines, such as the popular US gay journal The Advocate, and books widely available in other countries were regularly banned. Lesbian and gay publishers and book importers faced an uphill battle for survival. Otherworld Books, an independent book company, based in Cape Town, was but one example. Since it catered predominantly for the lesbian and gay market, it imported books on sexual theory, history, politics and culture. As late as 1992 Customs House in Cape Town confiscated every shipment of books bound for Otherworld, claiming possible contraventions of South African censorship laws.

In November 1993, in the waning days of Nationalist Party rule, representatives of 20 South African political parties, including the ANC, approved a draft constitution for a post-apartheid South Africa. The new constitution featured a Bill of Rights outlawing discrimination on the basis of a number of personal characteristics, ranging from race and gender to age and physical disability. It also included sexual orientation: South African gays and lesbians were at last considered as a part of this country. With countries like the United States of America still far from enacting gay civil rights protection, in just a few short years South Africa was leading the world with the most progressive constitution regarding gay and lesbian equality. It is still a long way to create total equality, since homophobia is still rife in rural South Africa and townships, and the vast majority of the population still lives in dire poverty. The country will still struggle for many years to come to address the imbalances left by apartheid, also within the film industry, which is still predominantly white (Botha 2003; 2012).

Under apartheid, many voices were thus silenced and marginalised in the film and television industries: blacks, women, gays and lesbians (Botha 2003). In 1989, Melanie Chait's Out in Africa became the first South African film to deal with gay and lesbian liberation struggle in South Africa. This short film is a moving tribute to two gay South African men, Simon Nkoli and Dr Ivan Toms, who were respected internationally for their stand against apartheid. Dr Toms was the first white South African to refuse to serve in the South African defence force. Simon Nkoli was one of the Delmas triallists. The film portrayed what it meant to be gay under apartheid and claimed that the South African liberation struggle is a movement for political as well as gay equality. Nkoli was arrested after a rent boycott demonstration in his home township of Sebokeng and was held in custody for 2 years before being charged, with 21 other prominent United Democratic Front activists, with treason. He became a cause célèbre after his arrest: The confluence of his open homosexuality and his imprisonment as a soldier against apartheid made him immensely appealing to liberation-oriented gay organisations around the world (Botha 2003; Peach 2007).

In Canada, the Simon Nkoli Anti-Apartment Committee became a critical player in both the gay and anti- 
apartheid movements. Gay film-maker John Greyson directed a short Canadian film, A Moffie Called Simon (1986), which became a confirmation of solidarity with the jailed activist. Through Nkoli's imprisonment, progressive members of the international anti-apartheid movement were able to begin introducing the issue of gay rights to the ANC. The highly respectable Anti-Apartheid Movements of both Britain and the Netherlands took up Nkoli's cause, and this was to exert a major impact on the ANC's later decision to include gay rights on its agenda for a democratic South Africa. By 1986 Nkoli was formally charged with murder but acquitted during the ensuing trail. In Beverley Ditsie and Nicky Newman's Simon \&J I (2001) Nkoli's relationship with fellow activist Beverley Ditsie is portrayed. It is a moving story of their battle against prejudice in any form, an effort which played an important role in ensuring constitutional protection of gay rights (Botha 2003).

Even more remarkable is Brian Tilley's It's My life (2003). Shot over 5 months, this co-production with France chronicles the activist activities of Zackie Achmat. Achmat took on the world's largest pharmaceutical companies and the South African government, fighting to ensure affordable treatment for people living with HIV. Initially his organisation, the Treatment Action Campaign (TAC) joined the South African government in a court case against pharmaceutical companies, hoping to facilitate a legal framework allowing for affordable anti-AIDS medication. However victory in court resulted in disappointment as the government refused to act on the advantages offered by the victory. Achmat, himself HIV positive, stunned the world by refusing to take medication as leader of the TAC because of his moral convictions: He took a controversial stance that he would not take anti-retroviral drugs until the government set up pilot anti-retroviral programmes at community clinics in all of South Africa's nine provinces (Botha 2003).

An important new voice in the creation of a South African gay and lesbian cinema is Luis DeBarros. He was a third-year BA student at the University of the Witwatersrand when he made (1992), a film about two male prostitutes. The film explores the possibility of male prostitution as a positive experience. His next film, Clubbing (1993), revolves around six 20-something-year-old friends who meet one evening before they go out clubbing. DeBarros captures the decline of a white ruling class in a society in which the rules are changing. They must come to terms with a future of uncertainty, a future no longer assured of privilege. Among the characters is an attractive gay male couple who comes across as three-dimensional. They are probably the first non-stereotypical male gays on South African screens (Botha 2003).

DeBarros's Hot Legs (1996) is a revenge fantasy, which revolves around Tim, a young gay doctor who wants to take revenge on Dave, a man he once loved, by holding him captive in a motel room for 6 days. Together the two characters relive their past and look at how they became the people they are. Although psychologically troubled, both characters are attractive, non-stereotypical gays. They do not fall in the traps of either being sissies or villains (according to Russo's reflections on the history of gay and lesbian representation in US cinema), just two human beings trying to sort out their conflicts within a homophobic society.

DeBarros's voice is loud and caustic; the audacity with which he tackles taboo subjects in a homophobic society can be seen as inspirational for other film-makers and for the fearless use of the medium to disseminate information about life in multiracial/multi-ethnic South Africa. Since the late 1990s DeBarros has been working on a feature on male homosexuality in South Africa, Pressure, but due to funding problems the end result has yet to be seen (Botha 2003).

One of the most important local gay film-makers remains Jack Lewis, who won acclaim for his two oral histories of gay subcultures in Cape Town. A Normal Daughter: The Life and Times of Kewpie of District Six (1997) depicts gay life in the former District Six through the memories and snapshots of the main character, a drag queen. In District Six, gays were an accepted part of a racially and religiously diverse community. Long before the emergence of the post-Stonewall gay scene in Cape Town, life in District Six was open and out. From the main protagonist's hairdressing salon the gays organised elaborate drag balls, cabaret performances and concerts. They colonised clubs, prepared food for weddings and funerals, styled everyone's hair and looked after the neighbours' children. Lewis captures this vibrancy lovingly by means of a collection of snapshots and interviews (Botha 2003). But sadly, Cape Town's District Six was physically destroyed by the apartheid government in the 1970s.

The sense of loss is also sensitively depicted in the other oral history by Lewis, titled Sando to Samantha: Aka the Art of Dikvel (1998). The video combines interview material with dramatised footage to reconstruct the 
life of Sando Willemse, a drag queen who served in the South African Defence Force until he was dismissed because of his HIV status. He turned to prostitution to survive and found friendship and support in a community of drag queens working in Cape Town streets. He died of HIV-related causes in 1996 aged 22. In this film, Lewis allowed Sando to narrate his own story in a beautiful blend of moving personal testimony and subversive commentary on South African politics (Botha 2003).

Lewis is also the co-founder of the South African Gay and Lesbian Film Festival (with Nodi Murphy). The first Out in Africa Gay and Lesbian Film Festival took place in South Africa in 1994, just after the new government came into power. The event was captured vividly by American lesbian director Barbara Hammer in her documentary Out in South Africa (1994) which became one of the first local media portrayals of black gay and lesbian activities. The media silence regarding township gays was finally shattered. Lewis's intention was to create a black audience for the festival by promoting gay films to township gays and lesbians.

A landmark television series by Zackie Achmat and Jack Lewis, titled Apostles of Civilised Vice (1999), address the various stereotypes around gay / lesbian history in South Africa from colonial times to the postapartheid era. Further stereotypes are addressed in Dark \& Lovely, Soft \& Free (2000), a documentary about a gay hairdresser, Zakhi. The film has been based on research by the Gay and Lesbian Archives of South Africa regarding the effect of the new constitution on the life of gay and lesbian people in small towns. Homelessness, homosexuality and prostitution are vividly examined in Four Rent Boys and a Sangoma (2003). The documentary deals with the lives of five men on the streets of Johannesburg. It is a provocative and intimate glimpse into the inner lives of these five men and the social milieu they inhabit.

The documentary Property of the State: Gay Men in the Apartheid Military (2003) is another significant visual chronicle of gay lives in South Africa. It brilliantly and sensitively deals with the stories of the uniformed men conscripted at a tender age into a brutal war machine with severe conformity and killing as its objectives. The film explores the complex space that was the South African military for gay men under apartheid. It includes heart-wrenching testimony from aversion therapy survivors, who underwent shock therapy in military hospitals to 'cure' their homosexuality. It looks at those cases where young men tried to commit suicide and those who ended up in the psychiatric ward. And it also deals with a patriarchal society where any weakness or softness in men was condemned and where some young men were subjected to male rape.

\section{A milestone in the $21^{\text {st }}$ century}

An important milestone in post-apartheid cinema is Lewis's Proteus (2003), the beginning of a visible gay/lesbian cinema in South Africa. The film is a collaborative effort between Lewis and John Greyson, building on the oral histories background of Lewis and the subversion of the period drama in previous Greyson films such as Lilies (1996), which is an adaptation by Michel Marc Bouchard and Linda Gaboriau of Bouchard's own play Les feluettes. It depicts a play being performed in a prison by the inmates. It covers a wide historical span (1912-1952) as the group of men in prison confront a bishop with his brutal response to their awakening homosexuality many years before.

Notions that homosexuality is un-African, an import of the western society, are brilliantly challenged in Proteus. Based on a true story, it is a period film, that raises issues still of enormous relevance today. As a historian and film-maker, Lewis was fascinated by a court record in the Cape Archives, dated 18 August 1735, giving judgement in the case of two Robben Island prisoners. Dutch sailor Rijkhaart Jacobsz and Claas Blank, a Khoe tribesman convict, received extreme sentences for what the court called 'the abominable and unnatural crime of Sodomy'.

Hees (2007) points out that, while based on extant court records, Proteus can hardly be read as a realistic account of the social construction of gender in the eighteenth century. The tension in the film between the attempt to depict the (historical) narrative of the prisoners as reflected in the court records of the time and the desire to explain their story with reference to a now suspect taxonomy is what generates and sustains its particular version of 'realism'. Proteus intends to generate a discourse on history, sexuality and identity construction. The way Proteus uses anachronism, for example, insistently draws attention to the film as a constructed historical discourse.

According to Hees (2007) the film departs radically from the norms governing the use of filmic space and time, 
and it does so precisely as a way of interrogating 'the relationship of past to present'. The opening credits state it is 'based on a true story', but it quickly becomes evident that historical authenticity is not what the film is striving for. Proteus opens by first signalling that past very clearly, then it almost immediately disrupts our sense of the historical period very deliberately - the key juxtaposition that we have to make sense of at the beginning of the film is South Africa in 1735 and court stenographers in 1964.

Greyson and Lewis indicated that they specifically referenced 1964 because that was the year that Mandela was incarcerated, but indicators such as the sixties court stenographers complete with cat-eye glasses and beehives also evoke this period when South Africa was drifting towards becoming a police state. In fact, Sergeant Willer's khaki uniform is that of the early apartheid period (as opposed to the later blue uniform). He is a key figure in the torture and incarceration of Claas Blank and Rijkhaart Jacobsz. At the start of the film we see him looming over Claas in the water-cell - the image is a chilling fusion of real and imaginary fear and anxiety, as will become clear - but for a South African viewer, at any rate, the khaki uniform is a powerful signifier of the growing state oppression (Hees 2007). The figure standing with Sergeant Willer, however, is dressed in an eighteenth-century military uniform.

The opening sequence indicates that the narrative is located in the decade between 1725 and 1735 . The opening images on screen are of protea flowers intercut with images of the 1735 court records and of the 60s stenographers struggling to find a way to translate the Dutch term for sodomy. Worden (2007) argues this is already an indication that the court records are themselves a mediated construction, but one could go even further and note that language itself is a highly unstable set of signifiers. Proteus suggests that language is an instrument to impose power, to torture, to deceive, to disguise and to generate panic. It is an extremely moving experience owing to the performances by Rouxnet Brown and Neil Sandilands and forms part of a very small number of South African productions on male homosexuality.

\section{Beyond 2003: Villains and victims}

Oliver Hermanus made an international impact with Shirley Adams (2009), a feature-length project coproduced by the London Film School (LFS) with Centropolis Entertainment and South African production house DV8. It was the final LFS project of Oliver Hermanus, who graduated in 2009 with the film. Set in Mitchell's Plain in Cape Town, it is the sensitive story of a mother who struggles to rehabilitate her son after he is paralysed by a gunshot wound. Denise Newman's portrayal of the mother is one of the highlights in South African cinema. Hermanus's depiction of characters at the margin of post-apartheid society is painful and moving. His second feature Skoonheid (2011) casts its main character, Francois van Heerden, according to Sonnekus (2013) as

"the archetypal disenfranchised white Afrikaner man, whose repressed homosexuality amplifies the anxiety and disempowerment he experiences in a post-apartheid world. His masculine identity is constantly under threat from racial and sexual 'Others', who highlight the hypocrisy and constructedness of the outmoded model of patriarchy that he reveres. A self-loathing and tragic figure, Francois ultimately seeks out the illicit and unattainable beauty embodied by his youthful object of affection, Christian, the son of a friend, and destroys it".

Unfortunately underdeveloped characters and a lack of psychological realism are problematic features of the film's screenplay and make such an ideological reading difficult, even after repeated viewings. Christian is an underdeveloped character. One simply doesn't understand why he would prefer to go to Francois's hotel room to ask for money instead of making the request in a public space such as a restaurant. When he rejects Francois's advances the older man attempts to rape him. There is not much psychological motivation for Francois's violent behaviour and the act appears as a rather clumsy narrative device. Christian as a character has been reduced to another victim on Russo's list. The director/screenwriter doesn't really examine Afrikaner patriarchy or the alienation of white Afrikaners in a post-apartheid society. The few incidents regarding racism are simply not enough to signify the archetypal disenfranchised white Afrikaner male, whose repressed homosexuality amplifies the anxiety and disempowerment he experiences in a postapartheid world. Hermanus's film is ultimately about villains and victims.

In an emerging gay cinema in South Africa, lesbians are almost remarkably absent: Quest for Love, The World Unseen (2008), My Black Little Heart (2008), and Barbara Hammer's documentary about South Africa after the 1994 elections, are among the few glimpses of this hidden reality. Shamim Sharif 's The World 
Unseen is a sensitive story of two Indian-South African women who fall in love in the racist, sexist society of apartheid South Africa in 1952. Claire Angelique's My Black Little Heart is a beautifully shot tale of a heroin user stuck in a Durban seaside vortex of decrepit flats and abandoned office blocks littered with self-mutilators, ex-cons, gangsters, street delinquents, hustlers and addicts. It includes moving images of lesbian love.

Recent images of gay men include supporting characters in Confessions of a Gambler (2007), Skilpoppe (2003) and Die Ongelooflike Avonture van Hanna Hoekom (The Incredible Adventures of Hanna Why, 2010). Unfortunately both Confessions and Skilpoppe reduced their gay characters to victims, both were AIDS victims. The Incredible Adventures of Hanna Why tells the tale of Hanna (Anneke Weidemann), a teenager with a wild imagination, and her unconventional family. Actress Anna-Mart Van der Merwe brilliantly portrays Hanna's artistic mother, while Gys de Villers plays her would be actor stepfather. Based on Marita Van der Vyver's youth novel, Van den Bergh's film is a refreshing portrait of an extended Afrikaner family, which in many ways deconstruct the images of conservative Afrikaners in the cinema of the 1970s. Hanna's biological father, for example, is a flamboyant queer (a fine performance by Tertius Meintjies), and the children embrace hip hop and are very much part of a post-apartheid South Africa.

\section{Conclusion}

Despite milestones such Proteus and The Man Who Drove with Mandela, as well as some innovative shorts and documentaries, many South African productions still feature fixed, stereotypical representations of local gay and lesbian identities. Hopefully a new generation of filmmakers and writers will break new ground instead of reproducing images that mainstream audiences expect.

\section{References}

Botha, M. P. 'Homosexuality and South African cinema'. Kinema, 19:Spring (2003), pp. 39-64.

Botha, M. P. (ed.). Marginal lives and painful pasts: South African cinema after apartheid. Cape Town, Genugtig!, 2007.

Botha, M. P. South African Cinema 1896 - 2010. Bristol, Intellect, 2012.

Botha, M. P. \& Swinnen, J. Opkomst van de representatie van lesbiennes en gays in de Zuid- Afrikaanse filmkunst: 1956-2003. In J. Swinnen (ed.) Anders zichtbaar. Zingeving en humanisering in de beeldcultuur (Brussels, VUB, 2010), pp. 173-207.

Gevisser, M. \& Cameron, E. (eds) Defiant desire: Gay and lesbian lives in South Africa. Johannesburg, Ravan, 1994.

Hees, E. Proteus and the dialectics of history. In M. P. Botha (ed.) Marginal lives and painful pasts: South African cinema after apartheid (Cape Town, Genugtig!, 2007), pp. 89-103.

Peach, R. Queer cinema as a fifth cinema in South Africa and Australia. Unpublished PhD thesis, University of Technology, Sydney, 2005.

Peach, R. Skeef cinema Entja: A brief history of South African queer cinematic cultures. In M. P. Botha (ed.) Marginal lives and painful pasts: South African cinema after apartheid (Cape Town, Genugtig!, 2007), pp. 51-87.

Pretorius, W. Afrikaans cinema. In J. Blignaut \& M. P. Botha (eds) Movies moguls mavericks: South African cinema 1979-1991 (Johannesburg, Showdata, 1992), pp. 375-94.

Russo, V. The celluloid closet: homosexuality in the movies. New York, Harper \& Row, 1987.

Sonnekus, T. (2013): 'We're not faggots!': Masculinity, Homosexuality and the Representation of Afrikaner Men Who have Sex with Men in the Film Skoonheid and Online, South African Review of Sociology, 44:1 (2013), pp. 22-39

Worden, N. 'What are we?': Proteus and the problematising of history. In V. Bickford-Smith \& R. Mendelsohn (eds). Black and white in colour, African history on screen (Cape Town, Juta, 2007), pp. 82-96. 


\section{Author Information}

Martin P. BOTHA is Associate Professor of Film and Media Studies at the University of Cape Town. He has published more than 200 articles, reports and papers on South African media, including six books on South African cinema. His most recent book is South African Cinema 1896-2010 (Bristol: Intellect, 2012). 